\title{
Serum Growth Hormone and Energy Supply in Fasting Obese Patients
}

\author{
By F. Schwarz, H. G. van Riet and W. Schopman
}

Serum growth hormone (GH) levels, plasma free fatty acids (FFA) and blood glucose were determined during periods of total starvation in 13 severely obese patients, 2 of whom were suffering from hypopituitarism, and in 2 normal volunteers. In all individuals nitrogen excretion was measured and the total caloric expenditure calculated. The percentile contribution of protein to total caloric expenditure (protein ratio $=\mathbf{P R}$ ) appeared to be lower in the obese than in the normals. GH-values rose steeply in the normals on starvation. In the serum of 4 of the obese no GH could be found, the others showed a slight to moderate response. When these 2 groups of obese were compared with regard to nitrogen excretion, caloric expenditure and PR, no difference was found. Both hypopituitary patients were treated with a small maintenance dose of cortisone. They tolerated starvation well. Their caloric expenditure was lower, but their nitrogen excretion as well as PR-values were in the same range as those of the other obese. From these findings it is concluded that in the obese patients studied, fat mobilization was certainly not impaired but rather more easily accomplished than in the normals. It appeared not to be dependent on demonstrable levels of serum-GH and is probably also independent from other anterior pituitary factors. Plasma-FFA rose less in the obese than in the normals. A slight correlation between $\mathbf{G H}$ and FFA but no correlation between blood sugar and GH was found on simultaneous determinations. (Metabolism 15: No. 3, March, 194-205, 1966)

$A^{\mathrm{D}}$

MINISTRATION of human growth hormone to human subjects causes nitrogen retention..$^{1-3}$ In dogs under conditions of restricted caloric intake growth hormone decreases protein breakdown. ${ }^{4}$ Furthermore, growth hormone increases the mobilization of fatty acids from the fat stores; plasma FFA levels rise, FFA are transferred to energy-requiring organs. ${ }^{5,6}$

During short fasting periods in man, Jansz et al. ${ }^{7}$ noted an increase of serum GH. In 1963 Roth et al. ${ }^{8}$ reported on a marked stimulation of the secretion of growth hormone in normal human beings during prolonged fasting. Several authors mention differences between $\mathrm{GH}$ - and FFA-levels of obese and of normal subjects. Obese patients responded to fasting with a smaller rise in plasma FFA, while GH-concentrations remained low. ${ }^{8,9}$ It has been inferred by some investigators ${ }^{8}$ that impaired fat mobilization due to lack of GH may

From the Departments of Theoretical Endocrinology and Internal Medicine, University Hospital, Utrecht (Holland) and the Laboratory for Endocrinological Chemistry of the Municipal Hospital at the Bergweg, Rotterdam (Holland).

Received for publication Oct. 21, 1965.

F. SGhwarz, M.D.: Head of Division of Endocrinology, Department of Internal Medicine, University Hospital of Utrecht, Holland. H. G. vAN RIET, M.D.: Assistant Department of Internal Medicine, University Hospital of Utrecht, Holland. W. Schopman, Pн.D.: Head of the Laboratory for Endocrinological Chemistry, Municipal Hospital at the Bergweg, Rotterdam, Holland. 
be one of the causes of obesity. The group of 10 obese females we reported about in a previous paper ${ }^{10}$ did not show any sign of insufficient fat mobilization during fasting periods of 10 days. In them, however, no GH-determinations had been done.

This paper deals with 13 additional patients in whom during total starvation GH-determinations were done next to determinations of FFA, blood sugar and of urinary nitrogen excretion. Two of these patients were suffering from hypopituitarism and one from diabetes mellitus. For comparison 2 healthy female volunteers were studied. As a parameter for the metabolic condition of the individual during starvation, the percentile contribution of protein breakdown to the total caloric expenditure has been used. This is called "protein ratio."

$$
\text { Protein Ratio }(P R)=\frac{\text { Energy, derived from protein }}{\text { Total calory expenditure }} \times 100
$$

If it is assumed that during food deprivation the body will draw preferentially from fat stores before breaking down protein, a low PR could be expected when energy from fat stores is readily available and a high PR when fat mobilization is impaired. Calculations of the PR have been done also on the 10 patients which were investigated formerly.

\section{Materials and Methods}

The age of the 11 obese female patients ranged between 22 and 64 years. The 2 obese male patients were 19 and 54 years old. Patient v. d. G. ( 23 yrs.) was an obese pituitary dwarf; patient G. B. (50 yrs.) was suffering from Sheehan's syndrome. In both patients the diagnosis of hypopituitarism was made on clinical grounds and verified hy detailed endocrinologic studies. During the period of observation both patients received only 12.5 $\mathrm{mg}$. cortisone thrice daily as a maintenance therapy. Prior to the study, the diabetic patient v. V. was regulated by 60 units of insulin daily.

As most patients were severely constipated during the total fast, it appeared to be diffcult to get a reliable demarcation of the several collection periods. As fecal nitrogen contributes only a minor and relatively constant amount to total excretion, 11 protein breakdown is calculated from urinary N-excretion only. The other methods employed were the same as described in a preceding paper. ${ }^{10}$

The 2 female volunteers were 18 and 23 years old and within normal limits of height and weight. After hospitalization they were for 4 days placed on a 1000 calory diet, containing $71 \mathrm{Gm}$. protein, $25 \mathrm{Gm}$. fat and $125 \mathrm{Gm}$. carbohydrate. Afterwards they went through a fasting period of 4 days. For comparison 5 of the obese patients had also an initial period of 1000 calories prior to the total fasting. The same methods of collection and laboratory determinations were used as in the obese group. In the obese subjects blood for GH-determinations was obtained on the first, seventh and tenth day of total starvation, and when possible, on the second, third and fourth day also. In the volunteers venous blood samples were taken daily at 8 a.m. Serum was introduced into glass tubes, frozen and preserved in a refrigerator. After collection of all samples, GII-determinations were perfurmed by one of us (W. S.) in the Isotope Department of the Municipal Hospital at the Bergweg, Rotterdam.

Scrum growth hormone was measured by radio-immuno assay comparable to the method of Glick et al.12

Human growth hormone was labeled with J-125 (Amersham IMS-3) by the Hunter, Grecnwood and Glover procedure. ${ }^{13}$ with purification by filtration over Sephadex-G 200 
according to Touber. ${ }^{14}$ Separation of free growth hormone from antibody-bound growth hormone was accomplished by evaporation chromatography on Whatman 3 MM paper.12

Raben growth hormone from human pituitaries was used as a standard, which assayed $1.5(0.9-2.2)$ unit of growth hormone/mg. (tibia test). Results are expressed in $\mathrm{m} \mu \mathrm{g} . / \mathrm{ml}$. of serum. The mean serum growth hormone level in 40 normal subjects after an overnight fast was $5 \mathrm{~m} \mu \mathrm{g} . / \mathrm{ml}$.

The total caloric expenditure of the obese patients has been calculated by the formula: 10 $7.2 \mathrm{~A}-6 \mathrm{ap}+600 \mathrm{~b}$

$$
\mathrm{a}+\mathrm{b}
$$

$\mathrm{A}=$ total weight loss

$\mathrm{a}=$ days 0 calories

$\mathrm{b}=$ days 600 calories

$\mathrm{p}=$ protein loss/day in $\mathrm{Gm}$.

This calculation is only valid if it is applied to a period of at least some weeks and could therefore not be used for the volunteers. In them calory requirement has been approximated by adding appropriate values from the tables of Passmore et al. ${ }^{15}$ to the BMR. Data for ideal weight were taken from the tables of the Association of Life Insurance Directors and Actuarial Society of America, 1912, p. 67.

\section{Results}

All obese patients tolerated fasting remarkably well. Hunger disappeared after the second or third day when ketonuria developed. In contrast, the normal volunteers excreted acetone on the first day of fasting and on the second day diacetic acid was found in the urine. In the diabetic insulin could be withheld during the starvation period without any untoward effect. On the fourth day of fasting, both volunteers complained of nausea and dizziness. After 110 hours the experiment had to be terminated; $\mathrm{HCO}_{3}^{-}$levels had dropped to 9.0 and $11.8 \mathrm{mEq}$./L., respectively.

\section{Nitrogen Excretion and the Percentile Contribution of Protein Breakdown to Calory Requirement}

Data for the average $\mathrm{N}$-excretion during the periods investigated, the calc11lated calory expenditure and the percentile contribution of protein breakdown to energy expenditure (PR) are given in Table 1 for the volunteers and for all patients.

In the obese group $\mathrm{N}$-excretion averaged $4.61 \mathrm{Gm}$./day (range 2.08-8.94 $\mathrm{Gm}$.). During their 4-day total fast the 2 volunteers excreted on the average 8.8 and $10.5 \mathrm{Gm}$./day, respectively. Calculated per $\mathrm{Kg}$. ideal body weight the $\mathrm{N}$-excretion of the obese subjects appears to be much lower $(0.065 \pm 0.023)$ than that of the volunteers $(0.149$ and $0.159 \mathrm{Gm}$., respectively).

The PR of 14 and 14.7 per cent calculated for the 2 volunteers, is in good agreement with data of Voit, ${ }^{16}$ who gives an average of 15 per cent for normals. In the 23 obese subjects we found an average PR of 5.1 per cent (S.D. 1.8 per cent). These low PR's were found irrespective of the height of the calculated calory requirement and of the age of the patients. This point

\footnotetext{
*Thanks are due to Dr. J. D. H. Homan, Organon N. V., OSS, for a generous gift of human growth hormone.
} 
requires special attention as the age of the 2 girl volunteers was much lower than the average age of the patients. If only PR-values found in obese female patients up to 25 years are considered, an average PR of 4.5 per cent (range 1.7-8.0 per cent) is found. The group of patients includes the 2 patients with hypopituitarism and the diabetic female. From these only the PR of patient G.B., suffering from Sheehan's syndrome, is remarkable because it is one of the highest we found in the obese ( 9.2 per cent).

As will be discussed later on, averages of 10 day periods might not be comparable to those of 4 day periods because $\mathrm{N}$-excretion can be expected to decrease in the course of starvation. Furthermore, the diet used before the fasting period might be of influcnce. Therefore, 5 obese women were pretreated exactly in the same way as the volunteers. The data found are shown in Table 2. It is apparent that during pretreatment as well as during starvation the nitrogen excretion is higher in the normals. The same applies to the PR-values found.

\section{Growth Hormone}

Data on the GH-response to prolonged fasting in normals are unfortunately scarce. Several investigators found a rise during fasting up to 24 hours. Roth et al. ${ }^{17}$ fasted one normal subject up to 60 hours, Beck et al. ${ }^{9}$ reported GHvalues in 5 normal subjects who were starved during 2 days.

In our volunteers starvation had to be terminated after 110 hours. In both, GH-values after the first overnight fast were practically zero (Fig. 1). In one patient there followed a sharp rise up to $31 \mathrm{~m} \mu \mathrm{g} . / \mathrm{ml}$. and after the second day a decline to low values. In the other, the rise was less steep but continued until the morning of the fifth day, when a value of $20 \mathrm{~m} \mu \mathrm{g} . / \mathrm{ml}$. was reached. Unfortunately, the value of the second day is missing.

Of 13 obese patients, in whom GH-determinations were done, 7 had on the first day serum levels above those of the normals. In one of them (patient Th.) the level was comparable to that reached by the volunteers; there was, however, no further rise to be seen. In 4 obese patients no GH $(<1 \mathrm{~m} \mu \mathrm{g} . / \mathrm{ml}$.) could be demonstrated throughout the whole experiment.

Figure 2 shows that in the volunteers FFA-levels were already above the normal range on the morning of the first day of starvation. In one patient a steep increase was noted; unfortunately, the determination of GH at that particular time is missing.

FFA-values in the obese patients at the start of the starvation lie in the range to be expected; the slow rise towards the end of the fasting corroborates the findings of Gordon ${ }^{18}$ and those of our previous study. ${ }^{10}$

GH-data during the first 4 days of starvation in the volunteers and in 5 of the obese patients are shown in Table 2.

In Figure 3 FFA-levels are plotted against the simultaneously determined $\mathrm{GH}$. There is a low grade correlation $(\mathrm{r}=0.33)$ which is significant $(\mathrm{p}<$ 0.01 ), but appears to be entirely due to the values found in the volunteers. In Figure 4 the same has been done for GH versus blood sugar values. No correlation could be found. Even samples in which the blood sugar was, for the methods used, in the hypoglycemic range, showed no GH-activity. 
Table 1.-Data for Percentage Overweight, Urinary Nitrogen Excretion, BMR, Calculated Energy Expenditure and "Protein Ratio" in 23 Obese Patients during Total Starvation of 10 Days and in 2 Normal Female Volunteers during a Total Fast of 4 Days

\begin{tabular}{|c|c|c|c|c|c|c|c|c|}
\hline Patient & Sex & Age & $\begin{array}{c}\% \text { Over- } \\
\text { weight }\end{array}$ & $\begin{array}{c}\text { Urinary } \\
\text { N-exer. } \\
\text { in Gm./day }\end{array}$ & $\begin{array}{c}\text { Urinary } \\
\text { N-excr. } \\
\text { Gm./day/ } \\
\text { Kg. ideal } \\
\text { weight }\end{array}$ & $\begin{array}{c}\text { BMR } \\
\text { Mean of } \\
3 \text { Determ. }\end{array}$ & $\begin{array}{c}\text { Cale. } \\
\text { Energy } \\
\text { Exp. }\end{array}$ & $\mathbf{P R}$ \\
\hline W. & 웅 & 23 & $5 \%$ & 8.8 & 0.149 & 1364 & 1664 & $14 \%$ volun- \\
\hline Vl. & 우 & 18 & $-6 \%$ & 10.5 & 0.159 & 1449 & 1749 & $14.7 \%$ y teers \\
\hline 1. v.d.G & q & 23 & $\begin{array}{l}37 \% \\
32 \%\end{array}$ & $\begin{array}{l}3.91 \\
2.57\end{array}$ & $\begin{array}{l}0.078 \\
0.051\end{array}$ & $\begin{array}{l}1075 \\
1081\end{array}$ & $\begin{array}{l}1651 \\
1651\end{array}$ & $\begin{array}{l}5.5 \% \\
3.6 \%\end{array}$ \\
\hline 2. G.B. & 우 & 50 & $7 \%$ & 8.02 & 0.123 & 1166 & 1737 & $9.2 \%$ \\
\hline 3. v.V. & 운 & 50 & $44 \%$ & 5.96 & 0.084 & $?$ & 2814 & $5.3 \%$ \\
\hline 4. v.R. & $\hat{\sigma}$ & 19 & $65 \%$ & 5.41 & 0.070 & 2523 & 2621 & $5.9 \%$ \\
\hline 5. K. & q & 43 & $39 \%$ & 4.80 & 0.073 & 1258 & 2056 & $5.3 \%$ \\
\hline 6. Rey. & 9 & 36 & $\begin{array}{l}35 \% \\
29 \%\end{array}$ & $\begin{array}{l}7.11 \\
5.01\end{array}$ & $\begin{array}{l}0.106 \\
0.075\end{array}$ & $\begin{array}{l}1333 \\
1437\end{array}$ & $\begin{array}{l}2794 \\
2794\end{array}$ & $\begin{array}{l}6.2 \% \\
4.2 \%\end{array}$ \\
\hline 7. B. & q & 64 & $\begin{array}{l}44 \% \\
31 \%\end{array}$ & $\begin{array}{l}8.94 \\
4.95\end{array}$ & $\begin{array}{l}0.119 \\
0.066\end{array}$ & $\begin{array}{l}1545 \\
1364\end{array}$ & $\begin{array}{l}2342 \\
2342\end{array}$ & $\begin{array}{l}9.5 \% \\
5.3 \%\end{array}$ \\
\hline 8. v.G. & q & 53 & $\begin{array}{l}81 \% \\
64 \% \\
60 \% \\
54 \%\end{array}$ & $\begin{array}{l}5.59 \\
4.30 \\
4.76 \\
3.41\end{array}$ & $\begin{array}{l}0.073 \\
0.056 \\
0.062 \\
0.045\end{array}$ & $\begin{array}{c}1780 \\
1751 \\
1788 \\
?\end{array}$ & $\begin{array}{l}2536 \\
2536 \\
2536 \\
2536\end{array}$ & $\begin{array}{l}5.5 \% \\
4.2 \% \\
4.3 \% \\
3.4 \%\end{array}$ \\
\hline 9. Th. & q & 19 & $36 \%$ & 8.48 & 0.130 & 1523 & 2651 & $8.0 \%$ \\
\hline 10. Veldh. & q & 46 & $\begin{array}{r}11 \% \\
7 \% \\
6 \%\end{array}$ & $\begin{array}{l}4.59 \\
5.16 \\
2.43\end{array}$ & $\begin{array}{l}0.064 \\
0.071 \\
0.034\end{array}$ & $\begin{array}{l}1145 \\
1201 \\
1275\end{array}$ & $\begin{array}{l}1801 \\
1801 \\
1801\end{array}$ & $\begin{array}{l}7.0 \% \\
7.2 \% \\
3.4 \%\end{array}$ \\
\hline 11. v.Es. & $\hat{\sigma}$ & 54 & $\begin{array}{l}35 \% \\
20 \%\end{array}$ & $\begin{array}{r}10.54 \\
7.20\end{array}$ & $\begin{array}{l}0.114 \\
0.078\end{array}$ & $\begin{array}{l}2556 \\
1928\end{array}$ & $\begin{array}{l}2590 \\
2590\end{array}$ & $\begin{array}{r}10.2 \% \\
6.9 \%\end{array}$ \\
\hline 12. v.O. & 우 & 22 & $\begin{array}{r}116 \% \\
97 \%\end{array}$ & $\begin{array}{l}5.30 \\
2.05\end{array}$ & $\begin{array}{l}0.083 \\
0.032\end{array}$ & $\begin{array}{c}2399 \\
?\end{array}$ & $\begin{array}{l}3027 \\
3027\end{array}$ & $\begin{array}{l}4.4 \% \\
1.7 \%\end{array}$ \\
\hline 13. $\mathrm{F}$. & ㅇ & 54 & $32 \%$ & 3.20 & 0.046 & $?$ & 2260 & $3.5 \%$ \\
\hline 14. Но. & $q$ & 26 & $\begin{array}{l}80 \% \\
71 \%\end{array}$ & $\begin{array}{l}4.22 \\
3.40\end{array}$ & $\begin{array}{l}0.067 \\
0.054\end{array}$ & $\begin{array}{l}1632 \\
1659\end{array}$ & $\begin{array}{l}2130 \\
2130\end{array}$ & $\begin{array}{l}5.0 \% \\
4.0 \%\end{array}$ \\
\hline 15. v.d.P. & q & 18 & $\begin{array}{l}41 \% \\
28 \%\end{array}$ & $\begin{array}{l}4.00 \\
2.86\end{array}$ & $\begin{array}{l}0.066 \\
0.048\end{array}$ & $\begin{array}{l}1639 \\
1304\end{array}$ & $\begin{array}{l}1960 \\
1960\end{array}$ & $\begin{array}{l}5.1 \% \\
3.6 \%\end{array}$ \\
\hline 16. Ru. & $q$ & 25 & $\begin{array}{l}70 \% \\
61 \%\end{array}$ & $\begin{array}{l}2.22 \\
2.08\end{array}$ & $\begin{array}{l}0.036 \\
0.034\end{array}$ & $\begin{array}{l}1573 \\
1313\end{array}$ & $\begin{array}{l}2046 \\
2046\end{array}$ & $\begin{array}{l}2.7 \% \\
2.5 \%\end{array}$ \\
\hline 17. E. & $q$ & 18 & $\begin{array}{l}37 \% \\
31 \%\end{array}$ & $\begin{array}{l}3.78 \\
4.59\end{array}$ & $\begin{array}{l}0.056 \\
0.068\end{array}$ & $\begin{array}{l}1509 \\
1417\end{array}$ & $\begin{array}{l}1647 \\
1647\end{array}$ & $\begin{array}{l}5.7 \% \\
6.9 \%\end{array}$ \\
\hline 18. Ko. & q & 39 & $\begin{array}{l}96 \% \\
88 \% \\
78 \%\end{array}$ & $\begin{array}{l}2.89 \\
2.94 \\
2.56\end{array}$ & $\begin{array}{l}0.046 \\
0.047 \\
0.041\end{array}$ & $\begin{array}{l}1798 \\
1562 \\
1517\end{array}$ & $\begin{array}{l}2233 \\
2233 \\
2233\end{array}$ & $\begin{array}{l}3.2 \% \\
3.3 \% \\
2.9 \%\end{array}$ \\
\hline
\end{tabular}


Table 1.-(Continued)

\begin{tabular}{|c|c|c|c|c|c|c|c|c|}
\hline Patient & Sex & Age & $\begin{array}{l}\text { \% Over- } \\
\text { weight }\end{array}$ & $\begin{array}{l}\text { Urinary } \\
\text { N-excr. } \\
\text { in Gm./day }\end{array}$ & $\begin{array}{c}\text { Urinary } \\
\text { N-excr. } \\
\text { Cm./day/ } \\
\text { Kg. ideal } \\
\text { weight }\end{array}$ & $\begin{array}{l}\text { BMR } \\
\text { Mean of } \\
\text { 3 Determ. }\end{array}$ & $\begin{array}{l}\text { Cale. } \\
\text { Energy } \\
\text { Exp. }\end{array}$ & PR \\
\hline 19. He. & $q$ & 48 & $\begin{array}{l}58 \% \\
48 \% \\
37 \%\end{array}$ & $\begin{array}{l}5.27 \\
5.98 \\
5.17\end{array}$ & $\begin{array}{l}0.068 \\
0.078 \\
0.067\end{array}$ & $\begin{array}{l}1513 \\
1458 \\
1718\end{array}$ & $\begin{array}{l}2423 \\
2423 \\
2423\end{array}$ & $\begin{array}{l}5.4 \% \\
6.2 \% \\
5.3 \%\end{array}$ \\
\hline 20. Ke. & q & 49 & $\begin{array}{l}57 \% \\
52 \%\end{array}$ & $\begin{array}{l}4.90 \\
3.58\end{array}$ & $\begin{array}{l}0.069 \\
0.051\end{array}$ & $\begin{array}{c}1866 \\
?\end{array}$ & $\begin{array}{l}1726 \\
1726\end{array}$ & $\begin{array}{l}7.1 \% \\
5.2 \%\end{array}$ \\
\hline 21. Bye. & $q$ & 52 & $\begin{array}{l}31 \% \\
22 \%\end{array}$ & $\begin{array}{l}4.42 \\
5.01\end{array}$ & $\begin{array}{l}0.055 \\
0.063\end{array}$ & $\begin{array}{c}1568 \\
?\end{array}$ & $\begin{array}{l}2449 \\
2449\end{array}$ & $\begin{array}{l}4.5 \% \\
5.1 \%\end{array}$ \\
\hline 22. Kol. & $q$ & 31 & $\begin{array}{l}39 \% \\
30 \%\end{array}$ & $\begin{array}{l}5.45 \\
5.30\end{array}$ & $\begin{array}{l}0.079 \\
0.077\end{array}$ & $\begin{array}{l}1495 \\
1525\end{array}$ & $\begin{array}{l}2863 \\
2863\end{array}$ & $\begin{array}{l}4.8 \% \\
4.6 \%\end{array}$ \\
\hline 23. D. & $q$ & 22 & $\begin{array}{l}49 \% \\
39 \% \\
34 \%\end{array}$ & $\begin{array}{l}6.48 \\
2.87 \\
3.18\end{array}$ & $\begin{array}{l}0.099 \\
0.044 \\
0.049\end{array}$ & $\begin{array}{l}1670 \\
1634 \\
1672\end{array}$ & $\begin{array}{l}2358 \\
2358 \\
2358\end{array}$ & $\begin{array}{l}6.9 \% \\
3.0 \% \\
3.4 \%\end{array}$ \\
\hline
\end{tabular}

Mean PR of the obese patients: 5.1 per cent (S.D. 1.8 per cent).

\section{Discussion}

The percentile contribution of protein breakdown to the total calory expenditure (protein ratio $=\mathrm{PR}$ ) has been found to be much lower in the obese than in the normals, irrespective of their age or of their tolal calory requirement. This could be due to facilitated mobilization of fat but one has to consider the possibility of a relatively reduced availability of protein in the obese.

The presence of very labile protein stores which can be turned into fuel even more easily than fat has been described by Allison ${ }^{19}$ for the dog. It is conceivable that these labile protein stores could be larger in normal individuals than in obese ones. Allison has inferred the existence of such stores from the slope of nitrogen excretion curves in dogs.

Such curves for our normals and for 5 of our patients are shown in Figure 5. It appears that there is no rapid decline of nitrogen excretion in the normal individuals nor, for that matter, an essentially different pattern in the obese. This would rule out a large difference in available labile protein stores as the cause of relatively greater fat mobilization in the obese. It would therefore seem to be probable that obese patients somehow are able to mobilize their fat more easily than normal individuals.

The situation of the obese patients could be compared to that of individuals fed a diet sufficient in calories but protein free. However, data from the literature ${ }^{20}$ indicate that under these conditions nitrogen excretion amounts to $2 \mathrm{mg}$. daily/basal calory, whereas in our group of obese patients it exceeded this value considerably, being on the average $2.98 \mathrm{mg}$. It is therefore questionable whether our starving obese patients can really cover their caloric needs by burning fat only. But it must be remembered that individuals on a protein free diet are consuming, next to fat, large amounts of carbohydrates which might have a protein-sparing action of their own. 


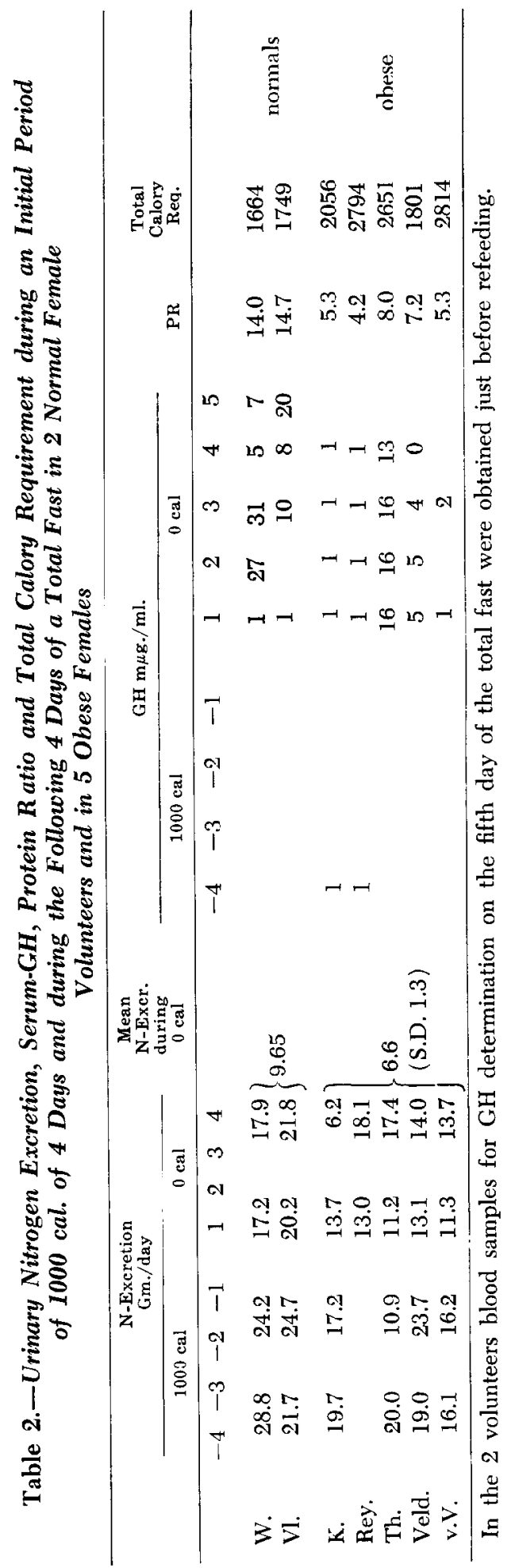




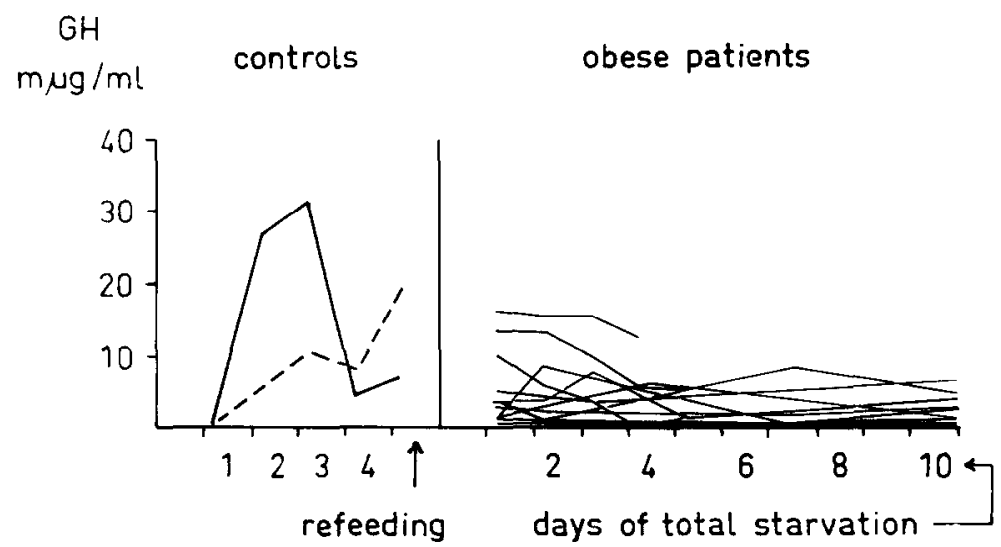

Fig. 1.-GH-levels in 2 normal female volunteers during 4 days of total starvation and in 11 obese females and in 2 obese males during 10 days total starvation.

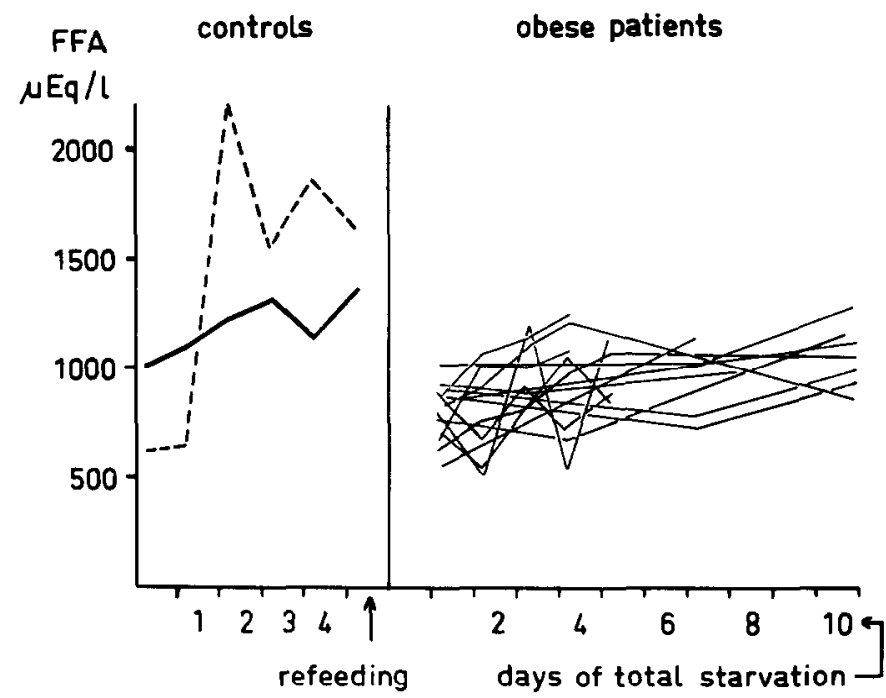

Fig. 2.-FFA-values in 2 normal female volunteers during 4 days of total starvation and in 11 obese females and 2 obese males during 10 days total starvation.

In the serum of 4 of our obese patients no significant growth hormone activity could be found throughout the whole experiment. In the others, values ranged between 2 and $16 \mathrm{~m} \mu \mathrm{g} . / \mathrm{ml}$. If those 2 groups are compared to each other, there appears to be no difference in nitrogen excretion, in calory expenditure or in PR-values (Table 3), whereas they both differ considerably from normal individuals.

It can be concluded that fat mobilization in the fasting obese is not dependent on demonstrable levels of serum growth hormone.

Fat mobilizing factors distinct from growth hormone have been isolated from the anterior pituitary gland by several investigators. ${ }^{21,22}$ We were curious therefore whether our hypopituitary patients who received only a small 


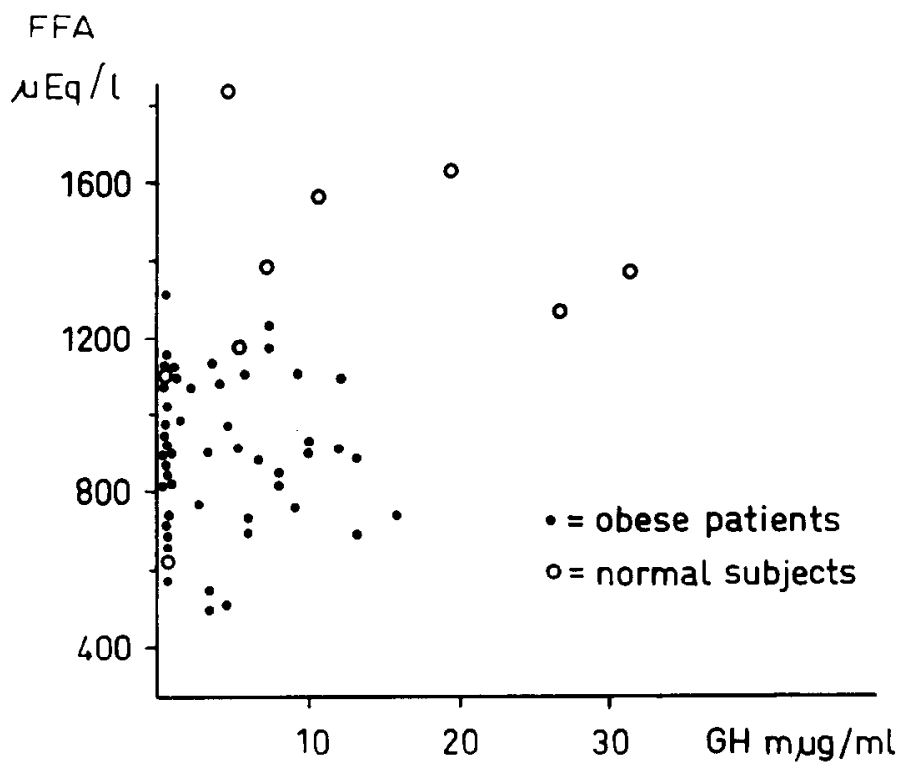

Fig. 3.-Simultaneous determinations of $\mathrm{GH}$ and FFA in 13 obese patients and 2 normal subjects during total starvation.

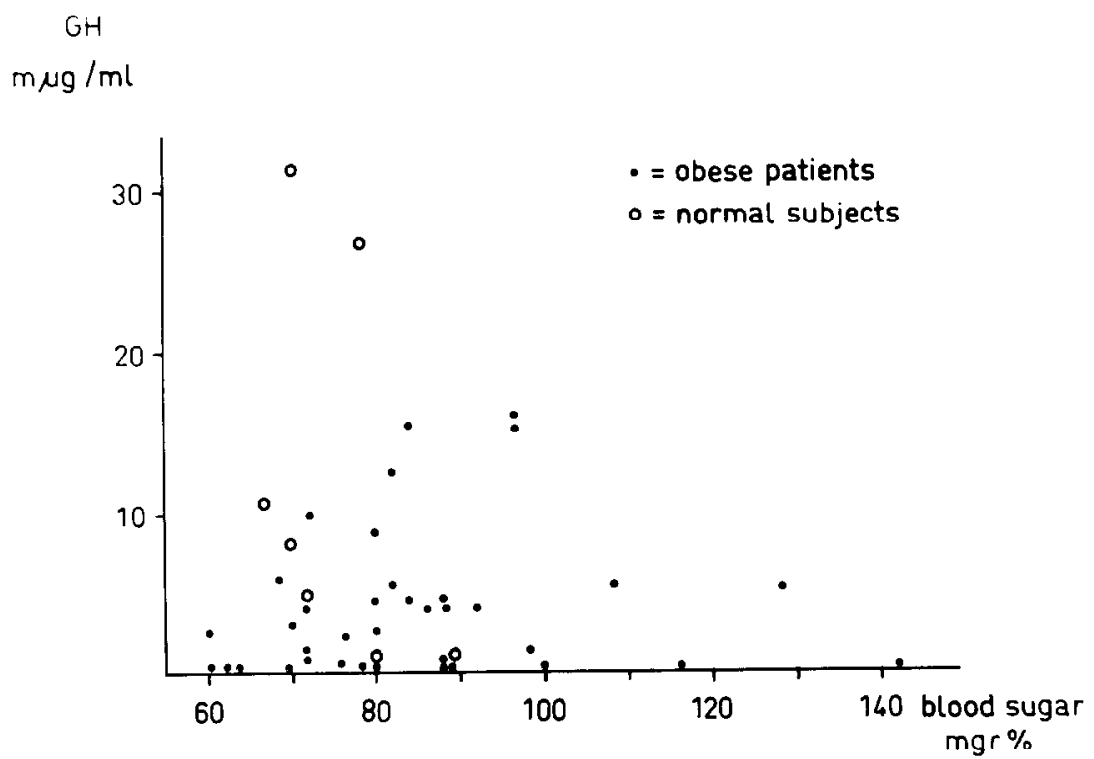

Fig. 4.-Simultaneous GH- and blood sugar determinations during total starvation of 10 days in 13 obese patients and in 2 normal subjects during a total fast of 4 days.

maintenance dosage of cortisone, would behave differently from the other obese patients. They tolerated fasting well but their calory expenditure appeared to be lower than that of the average obese (Table 3). In one of them, a patient suffering from Sheehan's syndrome, the PR-value found was rather high but still considerably lower than those of the normals. In the 

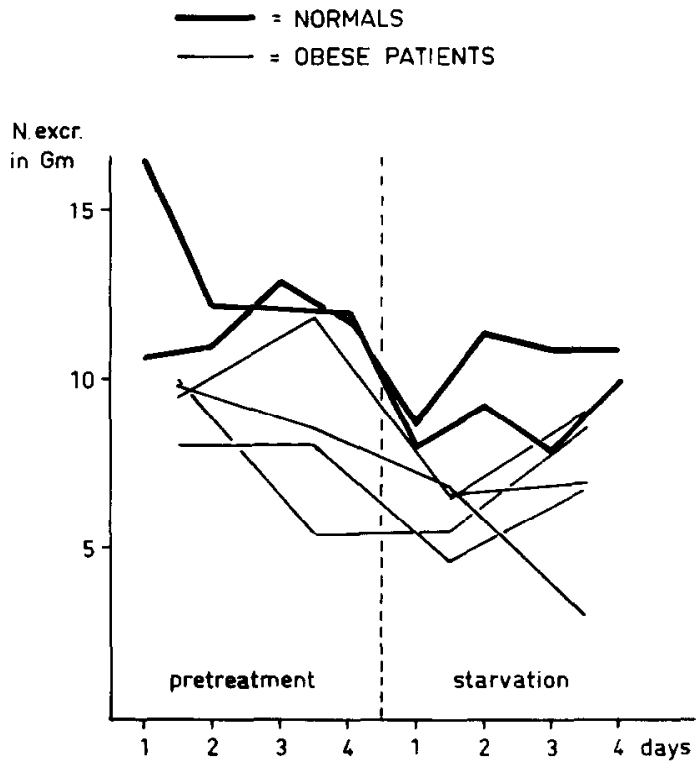

Fig. 5.-Urinary nitrogen excretion during a period of 4 days (diet 1000 cal./ day) and during a subsequent starvation period of 4 davs in 2 normal volunteers and in 5 obese females.

other, a pituitary dwarf, the PR-values were low. As far as conclusions can be drawn from this small number of observations, it seems likely that neither growth hormone nor other anterior pituitary factors are prerequisite for fat mobilization in the fasting obese.

There was a slight correlation between $\mathrm{GH}$ and FFA-levels determined in the same blood samples. But we were surprised to find no correlation whatever between blood sugar and GH-values; even some samples which showed blood sugar values in the hypoglycemic range, lacked GH-activity. Of course, that does not exclude a causal relationship because a time lag exists between hypoglycemia and the peak of serum-GH. But our patients were fasting continuously and it might be assumed that their blood sugar had been low for some time before the determination, so that $\mathrm{GH}$ response would have had time to develop. It seems therefore advisable to keep an open mind to the possibility that GH-release in long-term starvation is-at least partiallyregulated by factors other than the blood sugar level.

Finally, we want to comment on the fairly severe ketosis seen in our volunteers. It has been pointed out by several authors ${ }^{23}$ that the fasting obese is less prone to ketosis than the fasting normal. This has been attributed to a deficient mobilization of fat. From our data, however, it follows that ketosis developed in the normals while they were mobilizing less fat than the obese. It might be that the concentration of FFA in the plasma and not the absolute quantity of fat mobilized is responsible for the ketosis. Other possibilties to be considered include the high GH-level in the serum of the normals or some factor connected to the breakdown of protein tissue, 


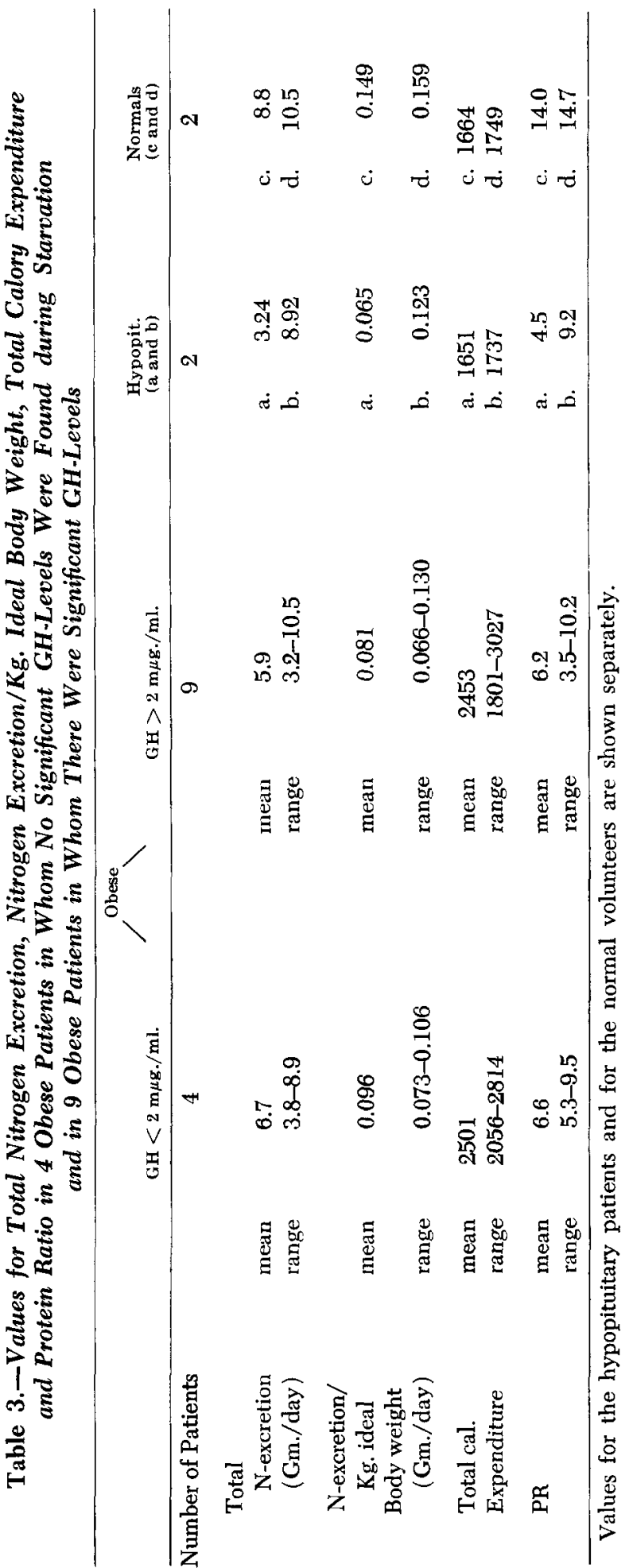




\section{ACKNOWLEDGMENT}

We are grateful to Dr. M. Tausk, Professor of Theoretical Endocrinology, State University of Utrecht (Holland) for reading the manuscript and for critical discussion.

\section{REFERENCES}

1. Beck, J. C., McGarry, E. E., Dyrenfurth, I., and Venning, E. H.: Metabolic effects of human and monkey growth hormone in man. Science 125:884, 1957.

2. Ikkos, D., Luft, R., and Gemzell, C. A.: Effect of human growth hormone in man. Lancet 1:720, 1958.

3. Henneman, P. H., Forbes, A. P., Moldawer, M., Dempsey, E. F., and Carroll, E. L.: Effects of human growth hormone in man. J. Clin. Invest. 39:1223, 1960.

4. Young, F. G.: Growth and diabetes in normal animals treated with pituitary (anterior lobe) diabetogenic extract. Biochem. J. 39:515, 1945.

5. Raben, M. S., and Hollenberg, C. H.: Growth hormone and mobilization of fatty acids. In Ciba Foundation Colloquia on Endocrinology, Human Pituitary Hormones, Vol. 13. 1960, p. 89.

6. - , and -: Effect of growth hormone on plasma fatty acids. J. Clin. Invest. $37: 922,1958$.

7. Jans7, A.. Doorenbos, H., and Reitsma, W. D.: Effect of food intake on growth hormone level. Lancet 1:250, 1963.

8. Roth, J., Glick, S. M., Yalow, R. S., and Berson, S. A.: Secretion of human growth hormone. Metabolism 12:577, 1963.

9. Beck, J., Koumans, J. H. T., Winterling, C. A., Stein, M. D., and Daughaday, W. H.: Studies of insulin and growth hormone secretion in human obesity. J. Lab. Clin. Med. 64:654, 1964.

10. van Riet, H. G., Schwarz, F., and der Kinderen, P. J.: Metabolic observations during the treatment of obese patients by periods of total starvation. Metabolism 13:291, 1964.

11. Salter. J. M.: Protein metabolism. In
Duncan, G. G. (Ed.): Diseases of Metabolism, Chap. 1. Philadelphia, Saunders, 1959.

12. Glick, S. M., Roth, J., Yalow, R. S., and Berson, S. A.: Immuno-assay of human growth hormone in plasma. $\mathrm{Na}$ ture 199:784, 1963.

13. Hunter. W. M., Greenwood, F. C., and Glover, J. S.: The preparation of J131 labelled human growth hormone of high specific radio-activity. Biochem. J. 89:114, 1963.

14. Touber, J. L., and Maingay, D.: Heterogeneity of human growth hormone. Its influence on a radio-immune assay of the hormone in serum. Lancet $1: 1403,1963$.

15. Passmore, R., and Durnin, J. V. G. A.; Human energy expenditure. Phys. Rev. 35:801, 1955.

16. Voit, E.: Ztschr. Biol. 41:188. 1901.

17. Roth, J., Glick, S. M., Yalow, R. S.. and Berson, S. A.: Hypoglycemia; a potent stimulus to secretion of growth hormone. Science 140:987, 1963.

18. Gordon, E. S.: First Intern. Congress of Endocr. Acta Endocrinol. (Kbh) 117: 1960 .

19. Allison, J. B.: Interpretation of nitrogen balance data. Fed. Proc. 10:676, 1951.

20. Hegsted, D. M.: J. Amer. Diet. A. 33: 225, 1957.

21. Rudman, D., Seidman, F., and Reid, M. B.: Lipemia-producing activity of pituitary gland: separation of lipemi:producing component from other pituitary hormones. Proc. Soc. Exp. Biol. 103:315, 1960.

22. Landolt, R., and Astwood, E. B.: Fat mobilization and hyperlipemia from pituitary extracts in rabbits. Amer. I. Physiol. 200:841, 1961.

23. Keckwick, A., Pawan, G. L. S., and Chalmers, T. M.: Resistance to ketosis in obese subjects. Lancet 2:1157, 1959. 